\title{
Article/Artigo
}

\section{Atypical lymphocytosis in leptospirosis: a cohort of hospitalized cases between 1996 and 2009 in State of Rio de Janeiro, Brazil}

\author{
Linfócitos atípicos na leptospirose: coorte de pacientes hospitalizados entre 1996 e 2009, \\ Estado do Rio de Janeiro
}

\author{
Paulo Vieira Damascoํㄹ ${ }^{1}$ Carlos André Lins Ávila ${ }^{1}$, Angélica Tápia Barbosa ${ }^{1}$, Marilza de Moura Ribeiro- \\ Carvalho $^{2}$, Geraldo Moura Batista Pereira ${ }^{2,3}$, Elba Regina Sampaio de Lemos ${ }^{4}$, Márcio Neves Bóia ${ }^{1}$ and \\ Martha Maria Pereira ${ }^{5}$
}

\begin{abstract}
Introduction: Leptospirosis is a zoonotic disease found in tropical and temperate countries, and its clinical diagnostic confusion with arboviruses (dengue fever, oropouche fever and yellow fever), Brazilian spotted fever, viral hepatitis and hantaviruses has been an ongoing public health concern. The aim of this observational study was to demonstrate an association between findings of atypical lymphocytosis and the progression of endemic leptospirosis. Methods: A retrospective analysis was performed on the demographic, epidemiological, clinical and laboratory aspects of 27 human leptospirosis cases that occurred over a period of 13 years (1996-2009) with no reported epidemic outbreaks in Rio de Janeiro, Brazil. Results: The overall mortality rate was $11.1 \%$ in our cohort of hospitalized cases. However, there was no mortality among patients with atypical lymphocytosis $(\mathrm{OR}=11.1 ; 95 \% \mathrm{CI}=1.12-110.9$; $p=0.04)$. Two patients who were in the septicemic phase showed signs of expansion of $\gamma \delta \mathrm{T}$ cell responses in peripheral blood. Conclusions: Atypical lymphocytosis may be observed in patients with leptospirosis. Our observations suggest that these atypical leukocyte subsets are associated with partial protection during the disease course of leptospirosis.

Keywords: Leptospirosis. Atypical lymphocytes. $\gamma \delta+\mathrm{T}$ cells. Clinical features.
\end{abstract}

\section{RESUMO}

Introdução: Leptospirose é uma zoonose que permanece endêmica em regiões tropicais e temperadas. A dificuldade no diagnóstico clínico diferencial entre os quadros de leptospirose humana e as várias arboviroses (dengue, febre amarela, febre de oropouche), febre maculosa brasileira, hepatite viral e hantavirose permanece um problema na Saúde Pública. Métodos: No presente estudo, foi realizada análise retrospectiva de características demográficas, epidemiológicas, clínicas e laboratoriais de 27 casos de leptospirose humana que ocorrerem durante um período de 13 anos sem ocorrência de notificação de surtos epidêmicos no Rio de Janeiro, Brasil (1996-2009). Resultados: A mortalidade da coorte de pacientes com leptospirose correspondeu a 11,1\%, sem embargo, o grupo de pacientes com atipia linfocitária não evoluiu para o óbito $(\mathrm{OR}=11,1 ; 95 \% \mathrm{CI}=1,12-110,9 ; \mathrm{p}=0.04)$. Em duas oportunidades, foi observada uma expansão dos linfócitos $\mathrm{T}$ gama-delta no sangue periférico de pacientes na fase septicêmica da leptospirose. Conclusões: Atipia linfocitária pode ocorrer em pacientes com leptospirose. Nossos dados também sugerem que os linfócitos atípicos podem estar envolvidos na patogênese da leptospirose.

Palavras-chaves: Leptospirose. Linfócitos atípicos. Linfócitos gama-delta. Características clínicas.

1. Disciplina de Doenças Infecciosas e Parasitárias, Universidade do Estado do Rio de Janeiro, Rio de Janeiro, RJ. 2. Laboratório de Imunopatologia, Universidade do Estado do Rio de Janeiro, Rio de Janeiro, RJ. 3. Laboratório de Microbiologia, Fundação Oswaldo Cruz, Rio de Janeiro, RJ. 4. Laboratório de Hantaviroses e Rickettioses, Fundação Oswaldo Cruz, Rio de Janeiro, RJ. 5. Laboratório de Referência Nacional para Leptospirose, Centro Colaborador da Organização Mundial da Saúde, Fundação Oswaldo Cruz, Rio de Janeiro, RJ.

Adddress to: Dr. Paulo Vieira Damasco. DIP/FCM/HUPE/UERJ. Av.Professor Manoel de Abreu 444/ $2^{\circ}$ andar - Vila Isabel, 20550-170 Rio de Janeiro, RJ, Brasil.

Fax: $55212587-6323$

e-mail: damascopv@ig.com.br

Received in $11 / 10 / 2010$

Accepted in 17/02/2011

\section{INTRODUCTION}

Leptospirosis is a zoonosis that is caused by infection with pathogenic Leptospira species. This disease is found worldwide in both temperate and tropical climates but its major health impacts have been underestimated in developing countries ${ }^{1}$; additionally, the disease has only recently been recognized as an emerging infectious disease ${ }^{2}$. Transmission from animal carriers to humans results from exposure to the urine of infected animals, either by direct contact or more frequently, through contaminated soil or water. The lack of a simple and reliable laboratory test, however, remains the major barrier for diagnosis and epidemiologic surveillance $^{1-3}$. A diagnosis may be made on the basis of the clinical presentation and symptoms that show characteristics of the severe disease form together with a suggestive epidemiological history $y^{3,4}$. However, a clinical diagnosis of leptospirosis is often inaccurate because the disease shares clinical features with a range of other infectious diseases ${ }^{5-8}$. Some of these other viral and bacterial infections, including some arboviruses (e.g., dengue fever, Oropouche fever and yellow fever), Brazilian spotted fever, viral hepatitis and hantaviruses, are matters of public health concern in tropical countries and may be related to the misdiagnosis of leptospirosis ${ }^{9,10}$. In one study in Thailand, the positive predictive accuracy of a hospital-based diagnosis of leptospirosis in nine provinces was low, with only 143 out of 700 (20\%) suspected cases being confirmed by laboratory testing. The causes of illness in the remaining $80 \%$ of cases were not found ${ }^{5}$. Furthermore, routine laboratory data are generally nonspecific; either a normal differential white blood cell count or a predominance of polymorphonuclear leucocytes is generally seen in leptospirosis cases. Peripheral lymphocytosis with the presence of circulating atypical lymphocytes is not described 
in leptospirosis but is often observed in a variety of diseases that closely mimic leptospirosis, including dengue, hantaviruses and viral hepatitis. However, the first reference to leptospirosis with atypical lymphocytosis and gamma-delta $\mathrm{T}$ cell responses in peripheral blood was recently described ${ }^{11,12}$. In this context, the aim of this observational study was to demonstrate an association between findings of atypical lymphocytosis and leptospirosis progression using a cohort of 27 patients who were admitted to a teaching hospital in the metropolitan area of Rio de Janeiro over a period of 13 years (1996-2009).

\section{METHODS}

\section{Study population}

A retrospective study was performed in Pedro Ernesto University Hospital, a 525-bed teaching hospital, over a period of 13 years (1996-2009). During this time period, human leptospirosis was endemic, with no reported epidemic outbreaks in Rio de Janeiro, Brazil. We described the demographic, epidemiological, clinical and laboratory characteristics of 27 confirmed human cases of leptospirosis.

\section{Case definition}

Patients with clinical suspicion plus a confirmatory laboratory test were defined as having leptospirosis ${ }^{13}$.

\section{Suspect cases}

Suspect cases included any patient with acute febrile syndrome with headache and myalgia and either an epidemiological history of disease or one of the following signs and symptoms: hemorrhagic suffusion, acute renal failure, jaundice or elevated bilirubin levels, hemorrhagic phenomena and/or pulmonary manifestations.

\section{Laboratory criteria}

Laboratory criteria included the following: I) reactive IgM enzyme-linked immunosorbent assay; II) microagglutination test (MAT) serum conversion; non-reactive test in the acute phase and a second positive test (14-21 days after the first test) with titles $\geq 200$; MAT titles four times higher between first and second blood samples with a 14-21-day interval; or a single MAT title $\geq 800$; III) Leptospira isolation in blood cultures; IV) Leptospira DNA detection with polymerase chain reaction (PCR); and V) immunohistochemistry, histopathological or PCR findings in necropsy.

\section{Study of the immune response}

Surface staining was performed using anti-CD14/PE, anti- $\gamma \delta /$ FITC, anti-HLA-DR/APC-Cy7, anti-CD3/PE, anti-CD4/APC, anti-CD8/PerCP and anti-CD19/FITC monoclonal antibodies $(\mathrm{mAb})$ that were purchased from Pharmingen/Becton-Dickinson (San Diego, CA).

\section{Sample collection, processing and cell separation}

Peripheral blood was collected from each patient using three 8-mL Vacutainer ${ }^{\circledR}$ CPT $^{\mathrm{m} x}$ (Cell Preparation Tube - BD, Franklin Lakes, NJ) containing sodium heparin as the anti-coagulant and one 8-mL green top Vacutainer ${ }^{\circledR}(\mathrm{BD}$, Franklin Lakes, NJ) to separate serum for other assays. The whole blood in the Vacutainer tube was transferred to a 50-mL conical tube (BD, Franklin Lakes, NJ), diluted to the same volume of PBS and then underlayed with $10 \mathrm{~mL}$ Ficoll-Hypaque (Pharmacia Fine Chemicals, Piscataway, NJ) density centrifugation. The tubes were centrifuged at $400 \times \mathrm{G}$ for $30 \mathrm{~min}$ at room temperature, after which time peripheral blood mononuclear cells (PBMCs) were collected at the interface layer. The PBMCs were washed twice with PBS and counted for recovery and viability using Trypan Blue (Sigma, St. Louis, MO).

\section{$T$ and $B$ cell phenotype determinations by flow cytometry}

PBMCs were plated in 96-well U-bottom plates ( $1 \times 10^{6} /$ well) and gently resuspended in $15 \mu \mathrm{L}$ of appropriately labeled human monoclonal antibodies as described above for $30 \mathrm{~min}$ at $4^{\circ} \mathrm{C}$. Following a wash in PBS-2\% fetal calf serum (FCS) solution, cells were centrifuged and harvested for cytometric analysis in a CyAn ${ }^{\text {тx }}$ ADP device (Beckman Coulter, Inc., USA). Viable lymphoid cells were defined based on forward and side scatter characteristics. Using the Summit Software v4.3.1 (EUV Technology SuMMIT, Martinez, CA) application, two gates were placed because the lymphocytes presented different sizes and granularities. These gates divided the lymphocyte population into small (typical) and large (atypical) lymphocytes and were drawn to exclude debris. A total of 20,000 cells were analyzed for each sample. Thresholds and statistical markers for positivity were set up using irrelevant isotypes conjugated in matched controls.

\section{Statistical analysis}

Statistical analyses were performed using GraphPad Prism 5.03 software. Dichotomous variables were comparable using the $\chi^{2}$ test with Yates correction, the two-tailed Mann-Whitney test for continuous variables and the Kaplan-Meier test for survival estimates. Significance was determined when the $p$ value was lower than 0.05 .

\section{Ethical considerations}

The research protocol (FR 320981) was approved by the Ethics Committee of Pedro Ernesto University Hospital.

\section{RESULTS}

The study enrolled 27 patients who were divided into one group with atypical lymphocytosis $(\mathrm{AL})(\mathrm{n}=15)$ and one group without atypical lymphocytosis $(n=12)$. The mean age was 35 years, without females under 40 years in our cohort. Seventeen (63\%) patients had an epidemiological risk of contracting leptospirosis. The main risk was associated with occupational activities. More comorbidities were seen in the AL group, but the differences were not statistically significant. There was no difference in the clinical manifestations and laboratory findings between the two groups (Table 1). Fever was recorded in $100 \%$ of the cases, following by myalgia and jaundice. The laboratory confirmation test was MAT in $22(81.5 \%)$ patients, but 2 leptospirosis cases were confirmed with PCR, and 3 were confirmed following necropsy. The predominant serovar was Copenhageni in both groups. In 14 patients, serum samples were also analyzed for other infectious diseases and serological tests for hantaviruses, spotted fever group rickettsia and dengue; the patients tested negative for all other diseases. The mean hospital stay was $12.8 \pm 10.2$ days, and $85.2 \%$ received antibiotic therapy. The following complications were found: $11.1 \%$ had clinical and electrocardiographic cardiology abnormalities; $48.1 \%$ developed acute renal failure according to RIFLE (Risk, Injury, Failure, Loss of function, and End-stage renal disease) criteria ${ }^{14}$; and $11.1 \%$ required dialysis support. Chest radiographic findings were observed in $48.1 \%$ of the patients; $25.9 \%$ developed respiratory failure, and $22.2 \%$ required invasive 
TABLE 1 - Demographics, clinical manifestations, laboratory findings and outcomes of patients with and without atypical lymphocytosis.

\begin{tabular}{|c|c|c|c|c|c|}
\hline Demographic characteristics & \multicolumn{2}{|c|}{ With AL $(n=15)$} & \multicolumn{2}{|c|}{ Without AL $(n=12)$} & P value \\
\hline age, median years (range) & \multicolumn{2}{|c|}{$26(18-46.5)$} & \multicolumn{2}{|c|}{$37(24.8-53.3)$} & 0.29 \\
\hline $\mathrm{n}$ of males/n of females & \multicolumn{2}{|c|}{$14 / 1$} & \multicolumn{2}{|c|}{$10 / 2$} & \\
\hline $\mathrm{n}$ of comorbidities & \multicolumn{2}{|c|}{6} & \multicolumn{2}{|c|}{2} & 0.37 \\
\hline Clinical manifestations & $\mathrm{n}$ & $\%$ & $\mathrm{n}$ & $\%$ & \\
\hline fever & 15 & 100.0 & 12 & 100.0 & \\
\hline myalgia & 15 & 100.0 & 11 & 91.7 & 0.9 \\
\hline jaundice & 14 & 93.3 & 10 & 83.3 & 0.84 \\
\hline hemorrhagic manifestations & 9 & 60.0 & 6 & 50.0 & 0.9 \\
\hline dyspnea & 6 & 40.0 & 4 & 33.3 & 0.32 \\
\hline neurologic manifestations & 3 & 20.0 & 4 & 33.3 & 0.73 \\
\hline \multicolumn{6}{|l|}{ Laboratory findings, median (range) } \\
\hline potassium (meq/1) & \multicolumn{2}{|c|}{$3.6(3.2-4.0)$} & \multicolumn{2}{|c|}{$3.6(3.0-4.2)$} & 0.88 \\
\hline creatinine $(\mathrm{mg} / \mathrm{dl})$ & \multicolumn{2}{|c|}{$1.9(1.2-3.6)$} & \multicolumn{2}{|c|}{$3.6(1.4-7.0)$} & 0.14 \\
\hline WBC count $\left(10^{3} / \mathrm{UL}\right)$ & \multicolumn{2}{|c|}{$15.1(11.1-21.1)$} & \multicolumn{2}{|c|}{$16.5(11.7-32.9)$} & 0.54 \\
\hline platelet count $\left(10^{3} / \mathrm{ul}\right)$ & \multicolumn{2}{|c|}{$84(40-148)$} & \multicolumn{2}{|c|}{$62.5(30-94.7)$} & 0.63 \\
\hline $\operatorname{albumin}(\mathrm{mg} / \mathrm{dl})$ & \multicolumn{2}{|c|}{$2.7(2.4-3.1)$} & \multicolumn{2}{|c|}{$2.9(2.6-3.0)$} & 0.87 \\
\hline Outcomes & $\mathrm{n}$ & $\%$ & $\mathrm{n}$ & $\%$ & \\
\hline antibiotic therapy & 14 & 93.3 & 10 & 83.3 & 0.84 \\
\hline chest radiographic findings & 3 & 20.0 & 4 & 33.3 & 0.73 \\
\hline respiratory failure & 2 & 13.3 & 5 & 41.7 & 0.22 \\
\hline acute renal failure (RIFLE criteria) & 7 & 46.7 & 6 & 50.0 & 0.83 \\
\hline
\end{tabular}

AL: atypical lymphocytosis, WBC: white blood cells, RIFLE: risk, injury, failure, loss, and end-stage Kidney classification.

mechanical ventilation. Four (14.8\%) patients developed hospitalacquired infections (Table $\mathbf{1}$ ). The thirty-day survival rate in the AL group was significantly higher than that of the group without $\mathrm{AL}$ ( $100 \%$ vs. $72.9 \%$, respectively). The OR was 11.1 ( $95 \% \mathrm{CI}=1.12$ - 110. 9; $\mathrm{p}=0.04)$ (Figure 1). The blood samples of two patients who were hospitalized in 2009 and belonged to the AL group were analyzed by flow cytometry using a CyAn ${ }^{\mathrm{TM}} \mathrm{ADP}$ device (Beckman Coulter, Inc., USA). Both patients were in the acute septicemic phase of infection. In both cases, striking AL was also associated with an increased frequency of $\gamma \delta$ T lymphocytes. Moreover, the $\gamma \delta$ T cells in the $\mathrm{AL}$ region presented upregulation of HLA-DR molecule surface expression expression (Figures $\mathbf{2}$ and $\mathbf{3}$ ).

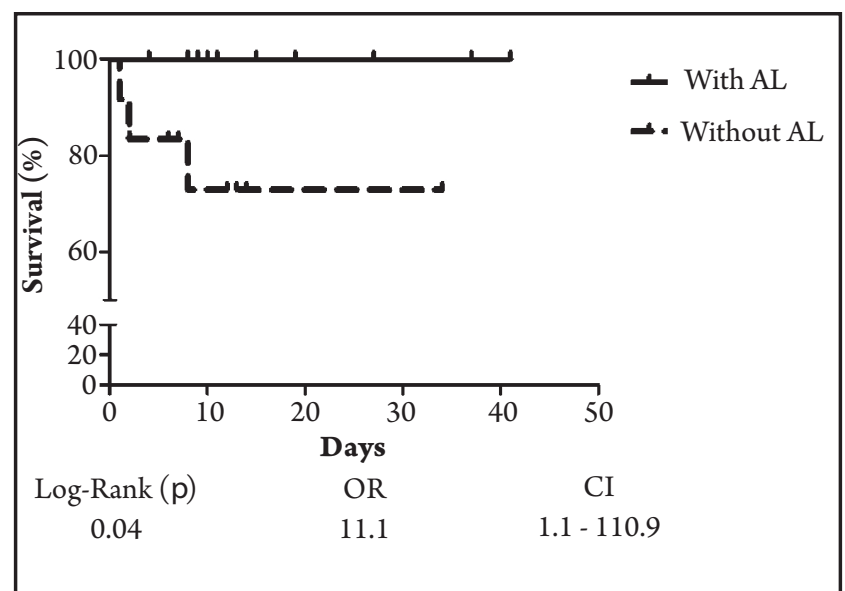

FIGURE 1 - Kaplan-Meier estimates of the survival rates of patients with leptospirosis with atypical lymphocytes and without atypical lymphocytes. AL: atypical lymphocytes, OR: odds ratio, CI: confidence interval.

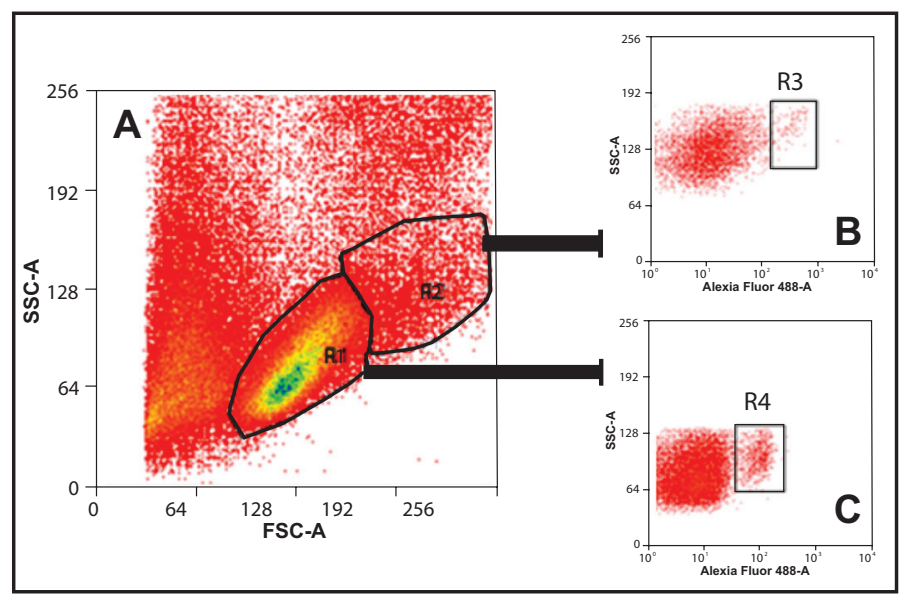

FIGURE 2 - In panel A: Dot plot showing peripheral blood mononuclear cells (PBMC) and the primary gating procedure for separating small lymphocytes (R1) and atypical lymphocytes (R2) based on side scatter (SSC) vs. forward scatter (FCS). B and C: dot plots showing $\gamma \delta$ lymphocytes $v$ s. SSC from atypical (R2) and small lymphocytes (R1). In panel B, 5,470 lymphocytes were counted, and 109 were $\gamma \delta^{+}(\mathbf{R 3})$. In panel $\mathrm{C}, 20,000$ lymphocytes counted, and 823 were $\gamma \delta^{+}(\mathbf{R 4})$. $\mathrm{R} 3$ = region 3; R4 = region 4. 

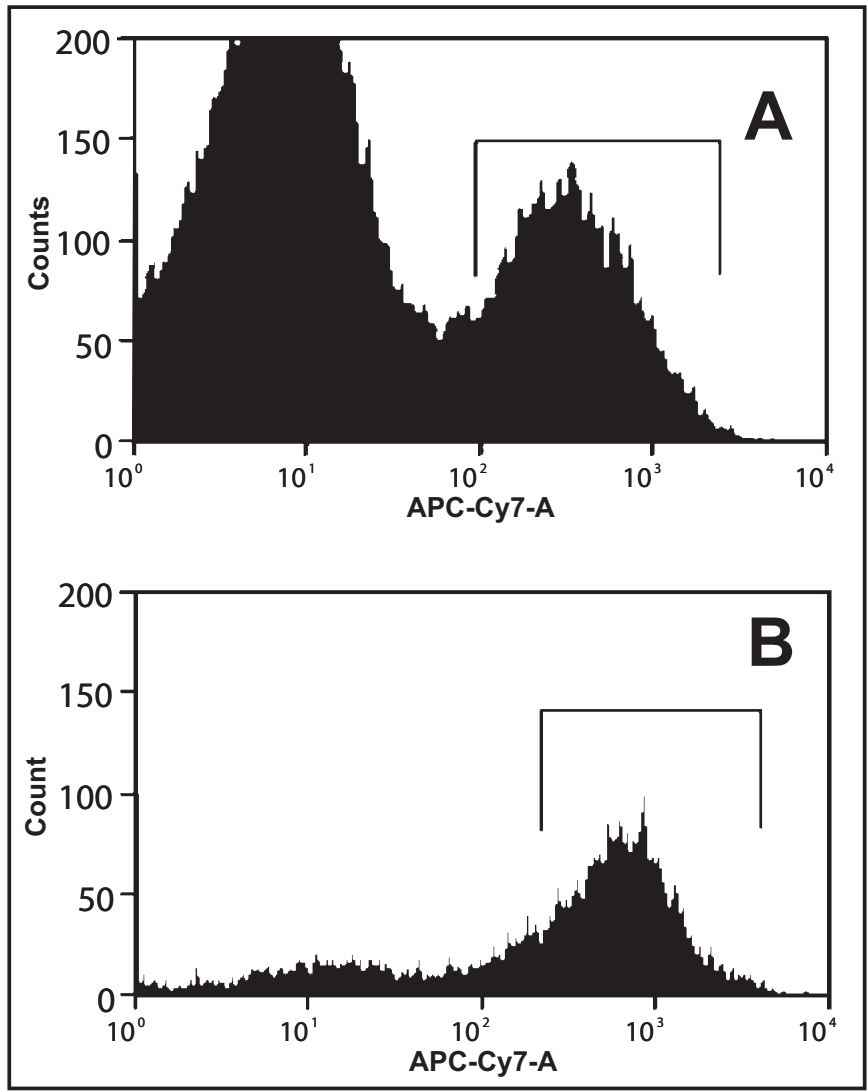

FIGURE 3 - Cell surface marker expression of HLA-DR on typical (panel A) and atypical lymphocytes (panel B) from PBMCs.Histograms showing immunofluorescence staining to HLA-DR. Bars indicate HLA-DR positive cells. There is an increase in HLA-DR expression levels (mean fluorescence intensity - MFI $)$ in atypical $($ MFI = 845.32 - B $)$ compared to typical lymphocytes $(\mathrm{MFI}=\mathbf{4 5 8 . 7 8}-\mathrm{A})$.

APC-Cy7 = Allophycocyanin (APC)-Cyanine dye (Cy7).

\section{DISCUSSION}

There are more than 250 serologically defined serovars of pathogenic Leptospira spp., which is currently divided into 15 genomospecies ${ }^{1,2}$. Infection by Leptospira spp. can lead to widely divergent clinical outcomes, including symptomatic infection, which is common in endemic regions; an undifferentiated febrile illness or an aseptic meningitis syndrome with low morbidity; or fulminant disease with a septic shock-like syndrome, jaundice, renal failure, myocarditis, hemorrhage, meningitis and death, which is observed during ongoing epidemics of severe leptospirosis in urban Brazil ${ }^{15-17}$. Severe pulmonary hemorrhage syndrome can be a prominent manifestation of this infection and may occur in the absence of hepatic or renal failure ${ }^{18}$.

Although leptospirosis has been described as a zoonosis of protean manifestations $\mathrm{s}^{1,2}$, in our cohort, fever, myalgia and jaundice were recorded in $100 \%, 96.9 \%$ and $90.9 \%$ of cases, respectively. Similar to the report of the Salvador Leptospirosis study group (Brazil) ${ }^{16}$, Ceará (Brazil) ${ }^{17}$ and Mexico ${ }^{19}$, cases admitted to the hospital developed signs of severe leptospirosis (Table 1). In our study, the overall mortality rate was $11.1 \%$, unlike the rates from Salvador ${ }^{16}$ and Ceará ${ }^{17}$, which were reported to be $15 \%$ and $15.4 \%$, respectively.

In our cohort, there was no statistical significance between groups with regard to demographic characteristics, clinical manifestations or laboratory data using a univariate analysis. Classical predictors of poor outcome, such as respiratory failure and acute kidney injury, were similar between groups.

The Kaplan-Meier analysis showed significant differences in survival rates when we compared the groups with and without atypical lymphocytes, suggesting that atypical lymphocyts may play a role in the outcomes of these patients (Figure 1).

The ubiquity of reactive lymphocytes suggests that they play an important role in the immune response. Atypical lymphocytes have been best studied from the blood of patients with Epstein-Barr virus (EBV), cytomegalovirus (CMV), toxoplasma infections, Q fever, rubella, roseola, herpes simplex, hemorrhagic fever, Rickettisialpox, mumps, adenovirus, influenza, tuberculosis, varicella, syphilis, HIV (types 1 and 2), hepatitis A, hepatitis B, Mycoplasma pneumoniae and Listeria monocytogenes ${ }^{20}$. There is only one case report associating atypical lymphocytes and $\gamma \delta \mathrm{T}$ cell expansion with leptospirosis ${ }^{12}$, and the main role of $\gamma \delta \mathrm{T}$ cells in the immune response to leptospirosis remains unclear $^{21} \cdot \gamma \delta \mathrm{T}$ cells constitute a small proportion (1-5\%) of the blood and peripheral organ circulating lymphocytes. However, several studies have reported major roles for these cells in an earlier pro-inflammatory response that produces IFN- $\gamma$ and other inflammatory cytokines, which is a link between the innate and adaptive immune responses, and a later regulatory response involving IL-10 production $^{22,23} \cdot \gamma \delta \mathrm{T}$ cells play an important role in host defense, and the expansion of the $\gamma \delta \mathrm{T}$ cell population is related to better outcomes in sepsis experimental models and other bacterial infections, including L. monocytogenes, Staphylococcus aureus, Streptococcus pneumoniae and granuloma formation in Mycobacterium tuberculosis and Schistosoma mansoni infections ${ }^{23-28}$.

Barry et al. ${ }^{12}$ described the first report of $\gamma \delta \mathrm{T}$ cell expansion in a patient with leptospirosis and atypical lymphocytosis. The authors suggested that this finding could be useful for the diagnosis of leptospirosis. Based on our results, the increased frequency of $\gamma \delta \mathrm{T}$ cells in the AL region raises the possibility that these cells play a role in the course of leptospirosis. Taken together, our observations suggest that these atypical leukocyte subsets are associated with partial protection during the disease course of leptospirosis. Prospective studies are in progress to explore the functional and phenotypic characteristics of $\mathrm{T}$ cell populations in human leptospirosis and to determine the relationship between $\gamma \delta$ T cells, the modulation of HLA-DR expression and clinical outcome and whether $\gamma \delta$ T cells play a protective role in leptospirosis.

The finding of an association between atypical lymphocytosis and $\gamma \delta$ T cell responses in peripheral blood with a milder form of human leptospirosis may be a key to understanding the immune response and resistance to infection by Leptospira spp.

\section{ACKNOWLEDGMENTS}

We wish to thank our team of physicians and nurses who cared for our patients in Pedro Ernesto University Hospital.

\section{CONFLICT OF INTEREST}

The authors declare that there is no conflict of interest.

FINANCIAL SUPPORT

Fundação de Amparo à Pesquisa do Estado do Rio de Janeiro. 


\section{REFERENCES}

1. Plank R, Dean D. Overview of the epidemiology, microbiology, and pathogenesis of Leptospira spp. in humans. Microb Infect 2000; 2:1265-1276.

2. Levett PN. Leptospirosis. Clin Microbiol Rev 2001; 14:296-326.

3. McBride A, Athanazio DA, Reis MG, Ko AI. Leptospirosis. Curr Opin Infect Dis 2005; 18:376-386

4. Agampodi S, Peacock S. The potential emergence of leptospirosis in Sri Lanka. Lancet 2009; 9:524-526.

5. Wuthiekanun V, Sirisukkarn N, Daengsupa P, Sakaraserane P, Sangkakam A, Chierakul W, et al. Clinical diagnosis and geographic distribution of leptospirosis, Thailand Emerg Infect Dis 2007; 13:124-126.

6. LemosER, Rozental T, Villela CL. Brazilian spotted fever: description of a fatal clinical case in the State of Rio de Janeiro. Rev Soc Bras Med Trop 2002; 35:523-525.

7. Levett PN, Branch SL, Edwards CN. Detection of dengue infection in patients investigated for leptospirosis in Barbados. Am J Trop Med Hyg 2000; 62:112-114.

8. LaRocque RC, Breiman RF, Ari MD, Morey RE, Janan FA, Hayes JM, et al. Leptospirosis during dengue outbreak, Bangladesh. Emerg Infect Dis 2005; 11:766-769.

9. Clement J, Maes P, Muthusethupathi M, Nainan G, van Ranst M. First evidence of fatal Hantavirus nephropathy in India, mimicking leptospirosis. Nephrol Dial Transplant 2006; 21:826-827.

10. Vinetz JM. Ten common questions about leptospirosis. Inf Dis Clin Pract 2000; 9:59-65.

11. Gubler D. Dengue and Dengue hemorrhagic fever. Clin Microbiol Rev 1998; 11:480-496.

12. Barry M, Wisnewski AV, Matthias MA, Inouye SK, Vinetz JM. Suburban leptospirosis: atypical lymphocytosis and $\gamma \delta \mathrm{T}$ cell response. Clin Infect Dis 2007; 43:1304-1307.

13. Ministério da Saúde. Leptospirose: Diagnóstico e manejo clínico. Brasília: Secretaria de Vigilância em Saúde; 2009.

14. Kellum JA, Bellomo R, Ronco C. Definition and classification of acute kidney injury. Nephron Clin Pract 2008; 109:c182-c187.

15. Gonçalves AJ, Carvalho JE, Silva JBG, Rosembaum R, Vieira AR. Hemoptysis and adult respiratory distress syndrome as causes of death in leptospirosis: changes in the clinical and anatomical pathological patterns. Rev Soc Bras Med Trop 1992; 25:261-270.

16. Ko AI, Reis MG, Dourado CMR, Johnson Jr WD, Riley LW. Urban epidemic of severe leptospirosis in Brazil. Salvador Leptospirosis Study Group. Lancet 1999; 354:820-825.

17. Daher EF, Lima RSA, Silva Junior GB, Silva EC, Karbage NNN, Kataoka RS, et al. Clinical presentation of leptospirosis: a retrospective study of 201 patients in a metropolitan city of Brazil. Braz J Infect Dis 2010; 14:3-10.

18. Zaki SR, Shich WJ. Leptospirosis associated with outbreak of acute febrile illness and pulmonary haemorrhage, Nicaragua, 1995. The Epidemic Working Group at Ministry of Health in Nicaragua. Lancet 1996; 347:535-536.

19. Zavala-Velázquez J, Cárdenas-Marrufo M, Vado-Solís I, Cetina-Cámara M Cano-TurJ, Laviada-Molina H. Hemorrhagic pulmonaryleptospirosis: three cases from the Yucatan peninsula, Mexico. Rev Soc Bras Med Trop 2008; 41:404-408.

20. Simon MW. The atypical lymphocyte. Inter Pediatrics 2003; 18:20-22.

21. Klimpel GR, Matthias MA, Vinetz JM. Leptospira interrogans activation of human peripheral blood mononuclear cells: preferential expansion of TCR $\gamma / \delta^{+}$vs TCR $\alpha / \beta^{+}$. J Immunol 2003; 171:1447-1455.

22. Hayday AC. $\gamma \delta$ Cells: A right time and a right place for a conserved third way of protection. Annu Rev Immunol 2000; 18:975-1026.

23. Born W, Cady C, Jones-Carson J, Lahn M, O’Brien R. Immunoregulatory functions of gamma delta T cells. Adv Immunol 1999; 71:77-144.

24. Venet F, Chung CS, Monneret G, Huang X, Horner B, Garber M, et al. Regulatory T cell populations in sepsis and trauma. J Leukoc Biol 2008; 83:523-535.

25. Sandor M, Sperling AI, Cook GA, Weinstock JV, Lynch RG, Bluestone JA. Two waves of gamma delta $\mathrm{T}$ cells expressing different $\mathrm{V}$ delta genes are recruited into Schistosome-induced liver granulomas. J Immunol 1995; 155: 275-284.
26. Tschöp J, Martignoni A, Goetzman HS, Choi LG, Wang Q, Noel JG, et al. Gammadelta $T$ cells mitigate the organ injury and mortality of sepsis. J Leukoc Biol 2008; 83:581-588.

27. Belles C, Kuhl AK, Donoghue AJ, Sano Y, O'Brien RL, Born W, et al. Bias in the gamma delta $\mathrm{T}$ cell response to Listeria monocytogenes. $\mathrm{V}$ delta $6.3+$ cells are a major component of the gamma delta $\mathrm{T}$ cell response to Listeria monocytogenes. J Immunol 1996; 156:4280-4289.

28. Poggi A, Catellani S, Musso A, Zocchi MR. Gammadelta T lymphocytes producing IFN-gamma and IL-17 in response to Candida albicans or mycobacterial antigens: possible implications for acute and chronic inflammation. Curr Med Chem 2009; 16:4743-4749. 